\title{
China's Entry Into WTO And Its Impact On EU
}

Ki Hee Kim, (Email: KimK@ wpunj.edu), William Paterson University

\begin{abstract}
The EU and China on May 19, 2000 reached a bilateral agreement toward China's membership in the WTO. The agreement brings China ever closer to completing its 14-yeas-old accession bid. China and the EU, two of the biggest markets in the world, have a everything to gain by deepening their commercial tides. Since 1978, EU and China trade has increased more than l0-fold. China is now the third largest important non-European trading partner. A strengthening of trade relations between China and EU is happening at the multilateral and bilateral level. Multilaterally, the EU is one of the keenest advocates of China's early accession to the WTO. Bilaterally, the EU supports China's economic and trade reforms, while encouraging further market opening. What is the EU's view on China's WTO accession? How does China's entry into WTO impact the EU? How will China benefit from joining the WTO? How does China's entry into WTO impact the EU? Will China comply with the agreements committed to EU? The purpose of this research is to evaluate trade performance, problems, current disputes, and other trade barriers between EU and China.
\end{abstract}

\section{Introduction}

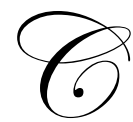

hina, one of the fastest growing economies in the world, has made tremendous progress in the last decade in reducing poverty and an economic system increasing open to trade and foreign investment. Now this economy will be subjected to the rules-based system of the WTO, something, which is bound to enhance global economic cooperation. On December 11, 2001 after 15 years of arduous negotiations, China became $143^{\text {rd }}$ member of the WTO. The opening of the economy China can be disruptive to some developing countries in the short-run, but in the long run, it should benefit not only China but also its trading partners. WTO membership likely incline China more toward peace and progress will take time. More importantly for the EU, joining WTO membership China will grant unprecedented access to the Chinese market for both EU exports and investments, including in politically sensitive sections and it will improve the chances for relations to develop peacefully on the basis of usual interest. One important reason to welcome China into WTO transcends mere commercial benefits. Promoting nondiscriminatory, multilateral commercial practices has been a central tenet of EU. Also, EU supports WTO membership for China, because it further opens the Chinese market to EU companies and products. China's entry into the WTO, a rules-based system that requires its members to operate with openness and transparency and stresses the central role of markets and private enterprise, is an important step to China's integration into the global community. The time and effort involved in negotiating these commitments and as a testament to China's determination to become a fully integrated player in the rules-based global trading regime. Although the battle to achieve the victory of WTO accession was hard fought, in many respects another equally worthwhile but difficult challenges confronts the nation.

\section{Benefits for China}

China's efforts to gain the WTO accession have been a complex, conflicting, lengthy, and multi-faceted process affected by many political, economic, and international factors. WTO to China is described by many as a long-term gain at the price of short-pain. Despite various debates and controversies on pros and cons, WTO membership will generate opportunities and challenges, benefits and risks, to the Chinese economy. China's economic research institutions estimated that, in approximately five years' time after China's entry, WTO membership will help China increase its annual GDP by 3-5 percentage points, double the country's foreign trade 
volume from 1998's US $\$ 320$ billion to US $\$ 600$ billion in 2005, and create million of new jobs. Major strategic benefits for China as a full WTO member include:

- A greater inflow of foreign investments as a result of improved investment environment; more international market access to advanced technology for Chinese enterprises.

- $\quad$ More equitable and non-discriminatory trading mechanism based on WTO rules and multilateral dispute resolution processes;

- $\quad$ Lower operation cost for Chinese enterprises to access foreign markets, and greater international pressure to expedite China's industry restructuring to obtain better competitiveness and efficiency; and

- $\quad$ Legitimization of China's role in establishing and enforcing global trading regulations.

In strategic and political terms, a developing China that gradually accepts international norms and integrates its economy with the rest of the world should be much better than an isolated and possibly unstable China.

\section{Highlights of the EU-China Agreement}

Telecommunications: The timetable for market opening in mobile telephony has been accelerated by 2 years. Foreign investment will be allowed at $25 \%$ on accession, $35 \%$ after one year and to $49 \%$ after 3 years. China will open up its leasing capacity from Chinese operators and resell it, for both domestic and international traffic.

Insurance: Effective management control has been negotiated for foreign participants in life insurance joint ventures, through choice of partner, and a legal guarantee of freedom from any regulatory interference in private contracts on a 50-50 equity basis. China will immediately give 7 new licenses to European insurers, in both the life and no-life sectors. Insurance business will be opened to foreign companies two years sooner than foreseen in the Sino-US agreement. Foreign brokers will be able to operate in China, free of any joint-venture requirement, 5 years after accession.

Monopoly State Import/Export Restrictions: China's state monopoly in importing crude and processed oil, and fertilizer, will gradually opened to private traders, starting on accession. The state monopoly on exporting silkwhere China accounts for 70\% of world production -will be completely removed by 2005 .

Tariffs: China has reduced import tariff on over 150 leading European exports-such as machinery, ceramics and glass, textiles, clothing, footwear and leather goods, cosmetics and sprits. Agreed levels are generally around 8$10 \%$.

Motor Vehicles: European carmakers are well established in China, and will have greater flexibility to choose which types of vehicles they build. China has agreed to eliminate the joint-venture restriction for engine production, upon accession.

Agriculture: Market access will improve for key EU products, such as rape-seed oil, dairy products, pasta, wine and olives.

Others: improved market access in the fields of banking, legal services, accountancy, architecture, tourism, construction, and dredging and market research. In addition to this agreement, China's official position on WTO has adhered to five points:

- $\quad$ The Chinese government takes a realistic, flexible, and active approach in seeking its WTO membership.

- $\quad$ The WTO is significantly deficient without China's participation.

- China is a developing country.

- $\quad$ China must be given a transitional grace period to gradually meet he WTO requirements.

- The Chinese government accepts the principle of "standstill" namely China will not, in the process of negotiation, promulgate new policies or laws that ate inconsistent with the WTO rules. 


\section{Non-tariff Barriers in China}

Non-tariff barriers to trade are administrated at national and sub-national levels by the State Economic and Trade Commission, the State Planning Commission, and Ministry of Foreign Trade and Economic Cooperation. China's NTBS include:

- $\quad$ Preferential trade policies.

- $\quad$ High tariff.

- $\quad$ Non-transparent trade rules and regulations.

- $\quad$ Trading rights.

- Investment Barriers.

- Import substitution policies.

- $\quad$ Export subsidies.

- Standards, testing, labeling, and certification.

- $\quad$ Government procurement policies.

- $\quad$ Services barriers.

- $\quad$ Anti-competitive practices.

- $\quad$ Tariff-rate quotas.

- $\quad$ Antidumping.

- $\quad$ Safeguards.

- $\quad$ Price control.

- $\quad$ Legal framework.

\section{China's Entry into WTO and Its Impact on EU}

Overall trade and economic cooperation between China and the EU is healthy but China is worried about import limits the EU imposed on some Chinese products. The total number of anti-dumping cases against Chinese products launched by he EU reached 91, accounting for about one-fifth of the total anti-dumping cases China faced. Opening of markets should be a two-way track. The EU side hopes China opens wider to the outside world, and China also hopes the EU opens to each other, can trade and economic cooperation grow to a better level. China's entry into the WTO is significant to the world trading system, especially now that there is a tendency to trade protectionism on the issue of steel. China-EU trade volume reached US\$78 billion last year, up 15\% from the previous year. Trade relations have been improving between China and EU but there are number of trade disputes that must be resolved. These include:

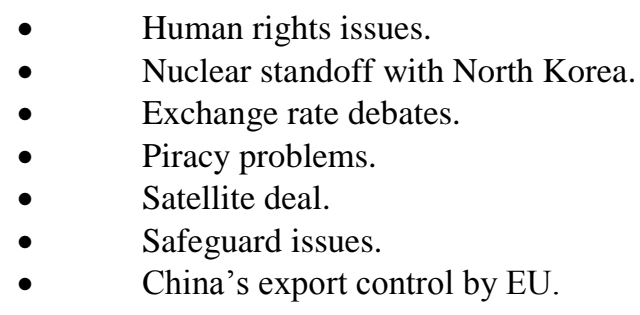

\section{The EU's China Policy}

The 2003 policy paper suggests ways of further developing EU-China relations by defining concrete and practical action points for EU policy towards china for the coming 2 to 3 years. The EU will enhance political dialogue through better focusing of the existing mechanisms and systematic inclusion of global and regional governance and security issues. The efficiency of the human rights dialogue is to be raised. In the economic and trade field, priority will be given to cooperation on the Doha Development agenda in WTO and monitoring China's 
compliance with its WTO commitments. Furthermore, the EC hopes to strengthen sector cooperation through the launch of the dialogues and agreements. Major agreements include:

- $\quad$ To engage China further on the world stage.

- To support China's transition to an open society based upon the rule of law and respect of human rights.

- To encourage the integration of China in the world economy and support the process of economic and social reform that is continuing in China

- $\quad$ To raise the EU's profile in China.

\section{Economic and Trade Relations}

China's rapid economic development in the past twenty years has had significant impact upon EU-China trade and economic relations. Total two-way trade has increased more than forty-fold since reforms began in China in 1978, as worth E115 billion in 2002. EU is China's second largest export market. In recent years, EU companies have invested considerably in China bringing stocks of EU FDI to over US\$33.9 billion. The EU trade deficit reflects among other things the effect of market access obstacles in China. EU policy in this area aims at the liberalization of trade and investment flows. The EU is fully committed to supporting China's reforms and liberalization through its cooperation programs. The present cooperation portfolio includes 40 projects for a total value of approximately E260m, which has been committed to in support of the general EU policies toward Chain.

\section{China's Performance in WTO and EU}

The EU assessment of China's performance "remain positive" one and a half years after China's entry into the WTO. The EU is extremely confident that the Chinese government will play a very constructive role in global trade. As EU-China trade ties continue to deepen, as our interdependence grows and our political relationship blossoms, the EU and China are becoming an ever close partnership" and that could be seen in the management of multilateral trade. China had a trade surplus of US $\$ 9.7$ billion with the EU in 2002 and the amount reached US\$4.3 billion in the first four months of in 2003. The two sides are sharing the same views on more and more international issues and economic and trade cooperation has been expanded and exchanges in cultural and scientific fields promoted between he two sides.

\section{Conclusion}

The EU welcomed China's accession to the WTO in late 2001, which came after 15 years of tough negotiations. China's accession was a historic leap for the WTO, enlarging its reach by 1.3 billion people in one step and making it truly global organization. Membership will bring benefits both and to its trading partners, cementing China" place in the global economy and ensuring a greater degree of certainty for traders in China and around the world. The EU is committed to giving further continuity to the dialogue, and to making it more results-oriented and better connected to decision-making in China so that it brings more tangible improvements. There will be trade problems and disputes between the two sides, but we are expecting positive trade relations between China and the EU for many years ahead.

\section{References}

1. $\quad$ WTO News, News Releases, Nov. 10, 2001.

2. Int'l Communications Studies Program, China's Accession and Its telecomm. Liberalization.

3. European Union in the U. S., News Release, May 19, 2000.

4. http: www.csis.org/ics/chinaswtoaccession.html.

5. http:www.chinaonline.com/csor/reference/rm-trade barriers-ch.asp.

6. DW.World. DE, Trade, North Korean Top Agenda at EU-China Summit, Oct. 30, 2003.

7. Europa, EU-China Summit: The EU's China Policy, March 11, 2003.

8. http:www.english.peopledaily com.cn/200306/14/enbg, 2003064.

9. Freee Republic, China and EU Enjoying Best Relations Ever in History, April 3, 2002. 